\title{
Effect of Tree Fertilization on Numbers and Development of Pear Psylla (Homoptera: Psyllidae) and on Fruit Damage ${ }^{1}$
}

\author{
D. G. PFEIFFER ${ }^{2}$ AND E. C. BURTS \\ Washington State University, Tree Fruit Research Center, Wenatchee, Washington 98801
}

\begin{abstract}
Environ. Entomol. 12: 895-901 (1983)
ABSTRACT Pear psylla, Psylla pyricola Foerster, egg and nymph density increased at a faster rate and reached higher levels on orchard pear, Pyrus communis L., trees receiving higher nitrogen application. This was probably due to psyllids ovipositing preferentially on foliage with higher nitrogen content. This perference was indicated in a choice chamber experiment using young and mature pear leaves. Differences in psylla densities on orchard trees due to nitrogen application rates were largely limited to the first half of the growing season. Nitrogen application rate had greater effect on psylla numbers than time of application (dormant vs. late summer). There was more russet damage to fruit from psylla on trees with a higher fertilization rate. Early-season nymphal populations were responsible for the differences in russet, highlighting the need for early-season control. Within certain ranges of foliar percent $\mathrm{N}$, psylla developmental rate increased with plant nitrogen content. At very low levels of foliar $\mathrm{N}$, however, psylla developmental rate also increased.
\end{abstract}

Pear psylla, Psylla pyricola Foerster, feeds on the phloem sap of pear, Pyrus spp. Most commercial pear cultivars grown in North America are derived from $P$. communis L., the favored host. Pear psylla is a serious pest of pear in all major North American pear-growing areas. Damage results primarily from honeydew produced by nymphs which russets fruit and causes a transpirational burn of the leaves.

There have been several works correlating psyllid infestations with tree nitrogen or vigor. Burts (1970) stated that the insects prefer young, succulent tissue, and that second and third generations favored terminal and water sprout growth. White (1970a) implicated nitrogen in feeding and oviposition site selection of the psyllid Cardiaspina densitexta Taylor on Eucalyptus fasciculosa F.v.M. Poor nitrogen supply was thought to be responsible for nymphal death in C. densitexta (White 1970b). This contributed to White's (1978) general hypothesis that nitrogen-deficient food limits abundance of animals, especially herbivorous insects, by lowering the survival rate of young individuals.

Since pear psylla was first introduced, control has relied mainly on insecticides, but pear psylla has consistently developed resistance to insecticides used against it. It is now recognized that currently available, effective insecticides must be used sparingly to postpone inevitable resistance (Croft and Hoyt 1978).

There is a need for more reliable, permanent management tactics against the pear psylla. One tactic which has several advantages such as compatibility with other practices and low cost to the grower is the modification of cultural practices (National Academy of Sciences [NAS] 1969). There has been relatively little work in this area relating to pear psylla. No experimental results have been reported dealing with the effects of nitrogen

'Received for publication 17 September 1982; accepted 13 January 1983. Scientific paper no. 6209, College of Agriculture Research Center, Washington State University, Pullman. Project no. 1531.

2Present address: Shenandoah Valley Research Station, Virginia Polytechnic Institute and State University, Steeles Tavem, VA 24476. supplied to the tree on pear psylla. It is the purpose of this study to examine the effects of varying rates and seasons of fertilizer application on pear psylla numbers, development, and damage.

\section{Materials and Methods}

A mature pear orchard (Pyrus communis cv. 'Anjou,' planted 1963-1965), to be called Smith Tract (ca. 16 $\mathrm{km}$ north of Wenatchee, in Douglas County) was fertilized with four different $\mathrm{NH}_{4} \mathrm{NO}_{3}$ treatments: $0.45 \mathrm{~kg}$ of actual nitrogen applied in dormant (early March), 0.45 $\mathrm{kg}$ of $\mathrm{N}$ applied in late summer (late August), $0.15 \mathrm{~kg}$ of $\mathrm{N}$ applied in dormant, and $0.15 \mathrm{~kg}$ of $\mathrm{N}$ applied in late summer. All rates are $\mathrm{kg}$ of $\mathrm{N}$ per tree; rates per ha $=$ rates $\times 270$. Treatments were applied in a randomized complete block (RCB) design with five blocks and four plots per block. Each plot included four trees, was separated from other plots by a buffer row of trees, and served as a replication of a treatment. Data were analyzed as a $2 \times 2$ factorial (rate and season of $\mathrm{N}$ application). The fertilization regime had been followed for the 4 years before the beginning of the study in 1980 . Hereafter, higher and lower $\mathrm{N}$ trees refer to trees receiving higher and lower rates of $\mathbf{N}$ application.

The test orchard was preconditioned for pear psylla each year by an application of fenvalerate (Pydrin 2.4 $\mathrm{EC}$ at $0.29 \mathrm{~kg} /$ liter), $340 \mathrm{~g}$ of $\mathrm{AI} / \mathrm{ha}$, plus horticultural oil (38 liters/ha) during the late dormant period. Amitraz (BAAM $20 \% \mathrm{EC}$ ), $1.7 \mathrm{~kg}$ of $\mathrm{AI} / \mathrm{ha}$, was applied to the orchard using an airblast sprayer on 24 July 1980 and on 2 July 1981 .

On each sampling date adults were counted by examining five beating tray samples (Burts and Retan 1969) from the four trees in a plot. Predators were also counted in 1981 . In 1980 , five shoots per plot per date were collected between 1 and $2 \mathrm{~m}$ high. Eggs and nymphs were counted on the distal five leaves and associated stem. The sampling dates are shown in Fig. 1 to 4 .

In 1981, the first summer generation was monitored by collecting fruiting spurs in the same manner as shoots 
in 1980 starting at full bloom. Eggs and nymphal instars were counted on each spur. A weighted mean instar formula (weighted instar

$$
W I=\underset{r=1.5}{j=1,5} I_{j} N_{r} / \sum_{r=1.5} N_{r}
$$

where $\mathrm{N}=$ number of individuals of instar $\mathrm{r}$, for 5 instars, and $\mathrm{I}=$ an integer multiplier from $\mathrm{j}=1-5$, to weight the respective instars) was used to estimate the psylla nymphal age structure. If all nymphs examined are 1 st instar, WI $=1$; if all are 5th instar, $\mathrm{WI}=5$, etc. When graphed over time, developmental rate is reflected.

On 29 June, egg and nymphal sampling was again directed to shoots. In 1981, however, a whole shoot was collected, and five leaves were picked from regular intervals (top, middle, and bottom leaf, and two more leaves interspersed).

Psylla damage was evaluated at harvest in terms of fruit size (weight of 25-pear subsamples; four subsamples per plot) and amount of downgrading due to honeydew russet. A weighted mean formula (downgrading index: DI $=[(\mathrm{n} 1)(0)+(\mathrm{n} 2)(2)+(\mathrm{n} 3)(4)] /[(\mathrm{nt})(4)]$, where $\mathrm{nt}=$ total number of pears in subsample, $\mathrm{n} 1=$ number of pears graded as U.S. $1, \mathrm{n} 2=$ number of pears graded as U.S. 2, and $n 3=$ number of pears graded as culls, was adapted from McVay and Ellis (1979) incorporating grades U.S. 1, 2, and cull. If all fruits in a sample are U.S. 1, DI $=0$; if all are culls, DI $=1.0$, etc.

The effect of pear psylla on tree vigor was evaluated by measuring the length of five shoots per tree ( 20 per replicate) in December 1980. Fruit bud density was determined by counting fruit buds per unit of limb crosssectional area during the tight cluster bud stage. Fruit set was calculated on the basis of 250 buds per replicate $(1,250$ buds per treatment; fruit set $=$ fruit per unit of limb cross-sectional area). Buds and fruit were counted in spring and summer 1981 .

In $1980, P$. communis $\mathrm{cv}$. 'Bartlett' seedlings about $0.7 \mathrm{~m}$ tall growing in ceramic crocks were divided into three groups based on initial shoot length such that differing lengths were spread evenly across the groups. Soil nitrogen was initially leached from the pots by flushing with water for $1 \mathrm{~h}$, and shoots were removed to stimulate fresh growth. Urea treatments $(0.5$ and $2.0 \mathrm{~g}$ of urea per 0.5 liters of water) were applied weekly. The third group received water only.

Thirty pear psylla in a 1:1 sex ratio were held for 5 days for oviposition on trees covered with 1.2-m-tall plastic cylindrical cages with organdy tops. Pear psylla adults and cages were then removed, and the resulting immature stages were allowed to develop in a growth room (LD $16: 8 ; 26.7^{\circ} \mathrm{C}$ ). The same experiment was repeated in 1981 , using 40 psylla per tree for 6 days. Nymphal instar determinations were carried out weekly (twice weekly in the latter half of the cycle) on four trees per treatment, two branches on three of the trees, one branch on the fourth, and 7 to 10 leaves per branch. The WI formula was also applied here. The WI curves were compared over the treatments by using the SAS GLM (LSMEANS) procedure (Helwig and Council 1979).

Young and mature leaves were compared in terms of pear psylla ovipositional preference in choice chambers modified from Chang and Philogène (1976). Modifications were the use of nine compartments rather than five, and the addition of a hole in the outer wall of each compartment such that the leaf petiole could protrude into a vial of distilled water in an attempt to delay effects of autolysis.

\section{Results and Discussion 1980 Orchard Studies}

Higher nitrogen application rates resulted in higher pear psylla egg and nymphal densities. The 1980 population curves for eggs and nymphs, where there were significant effects of rate and season of fertilizer application, are shown in Fig. 1 to 3. On a date-by-date basis, the higher $\mathrm{N}$ rate caused higher egg and nymph numbers predominantly on the early sampling dates (there was an $\mathrm{N}$ rate $\times$ sampling date interaction in egg numbers). The difference in egg numbers due to $N$ rate on 22 September may have been due to a late season flush of growth on high- $\mathrm{N}$ trees, providing preferred oviposition sites. Altering the $\mathrm{N}$ application rate caused differences in egg and nymph numbers averaged over the whole season (Table 1).

Season of $\mathrm{N}$ application had little effect on egg or nymph numbers. The only effect was on 20 July 1980 , when trees fertilized in dormant season had more nymphs than did those fertilized in late summer (Fig. 3). The effect of season of nitrogen application on pear psylla nymph numbers on that date could have been due to trees fertilized in the previous summer using up a large portion of their $\mathrm{N}$ resources by this date. But, since there was no concurrent (or earlier) difference in egg numbers due to season of $\mathrm{N}$ application, it is also possible that there was reduced nymphal survivorship on the late summer-fertilized trees.

There were steeper regression slopes for egg and nymph numbers on trees with high rates of fertilization over the first four sampling dates (when most significant differences occurred) (Table 2). This means that not only are pear psylla numbers greater on higher $\mathrm{N}$ trees, but psylla populations on such trees are also increasing faster than on lower $\mathrm{N}$ trees. Female pear psylla apparently lay eggs preferentially on foliage of trees with a higher nitrogen application rate, which causes a greater rate of increase in nymph numbers. The choice chamber experiment also showed that female psylla laid more eggs on younger leaves when given a choice between young and mature leaves (Table 3). Such leaves generally have higher amino acid levels (Hill 1980). Watmough (1968) found that psyllids on Sarothamnus make trial probes into the plant before ovipositing. This may be a general mechanism for determining host suitability by psyllids. The mandibular stylets of $P$. pyricola are each innervated by two dendrites and are probably used in some phase of host selection (Forbes 1972). 


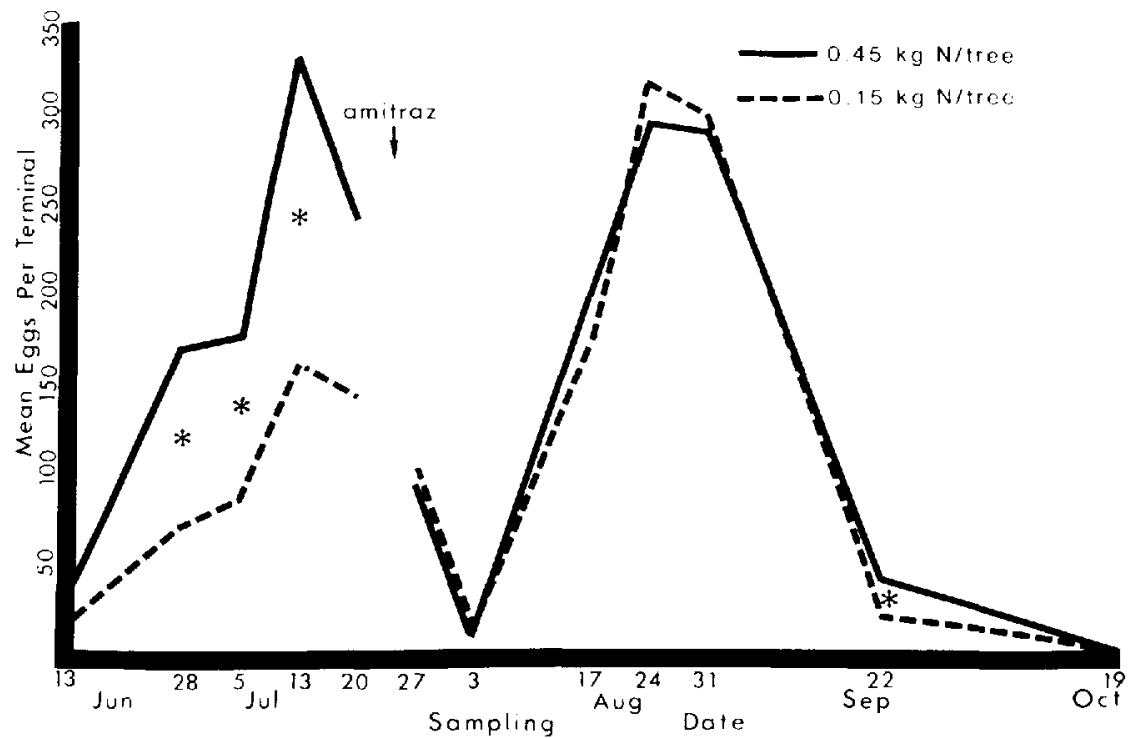

Fig. 1. Effect of fertilization rate on pear psylla egg numbers (Smith Tract, 1980). Asterisk indicates dates on which means are significantly different $(P<0.05)$.

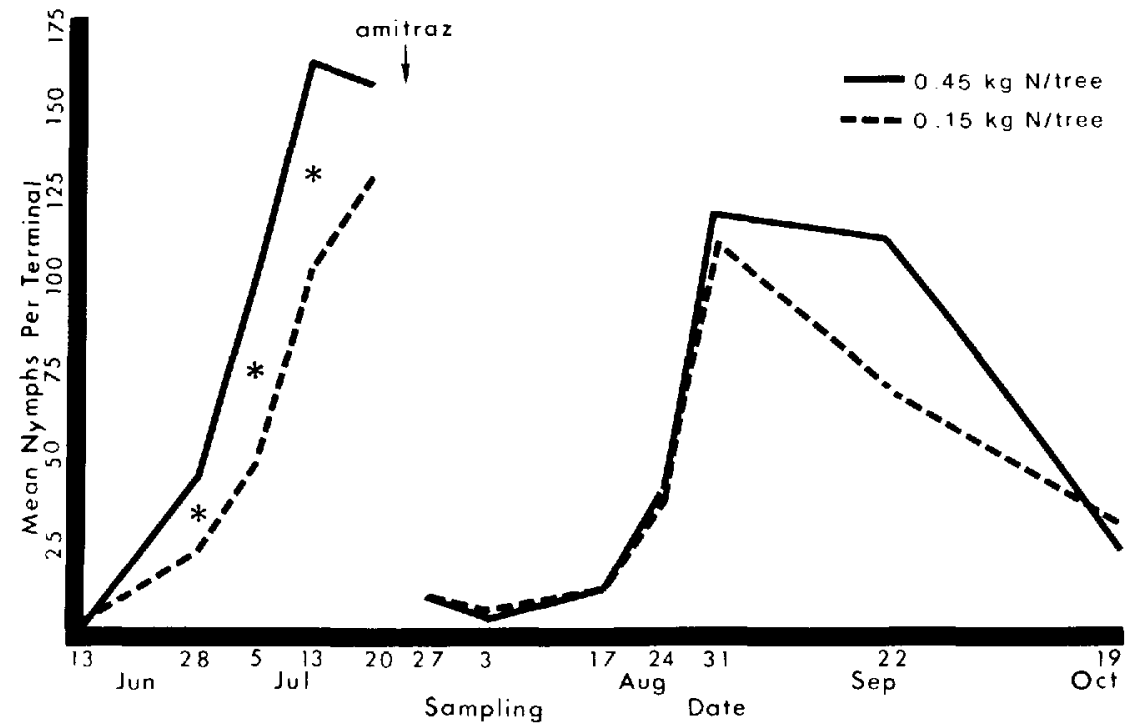

Fic. 2. Effect of fertilization rate on pear psylla nymph numbers (Smith Tract, 1980). Asterisk indicates dates on which means are significantly different $(P<0.05)$.

The only differences in adult populations during 1980 occurred on 13 July when there were more adults on the bate-summer-fertilized trees. There was no difference between the regression lines describing adult populations (Table 2). This lack of observed differences in adult numbers was probably due to movement of this stage between plots. One of the most important factors determining numbers of adult psyllids on Sarothamnus is dispersal from the breeding site (Watmough 1968). The sampling method employed may also have contribvted to dispersal of adults among the small plots.

\section{Orchard Studies}

When nymph numbers were averaged over the sampling period for first-generation pear psylla in 1981, the only differences $(P<0.10)$ due to rate of $N$ were observed in 4 th instars and total nymphs. Other instars showed some interaction between $\mathrm{N}$ rate and sampling date (e.g., rate $\times$ season $\times$ date for the 5 th instar) (Pfeiffer 1982). When interactions were examined in greater detail, $\mathrm{N}$ rate was seen to affect nymph numbers progressively later for each succeeding instar, a "pulse" moving through the cohort. There were more 1 st nym- 


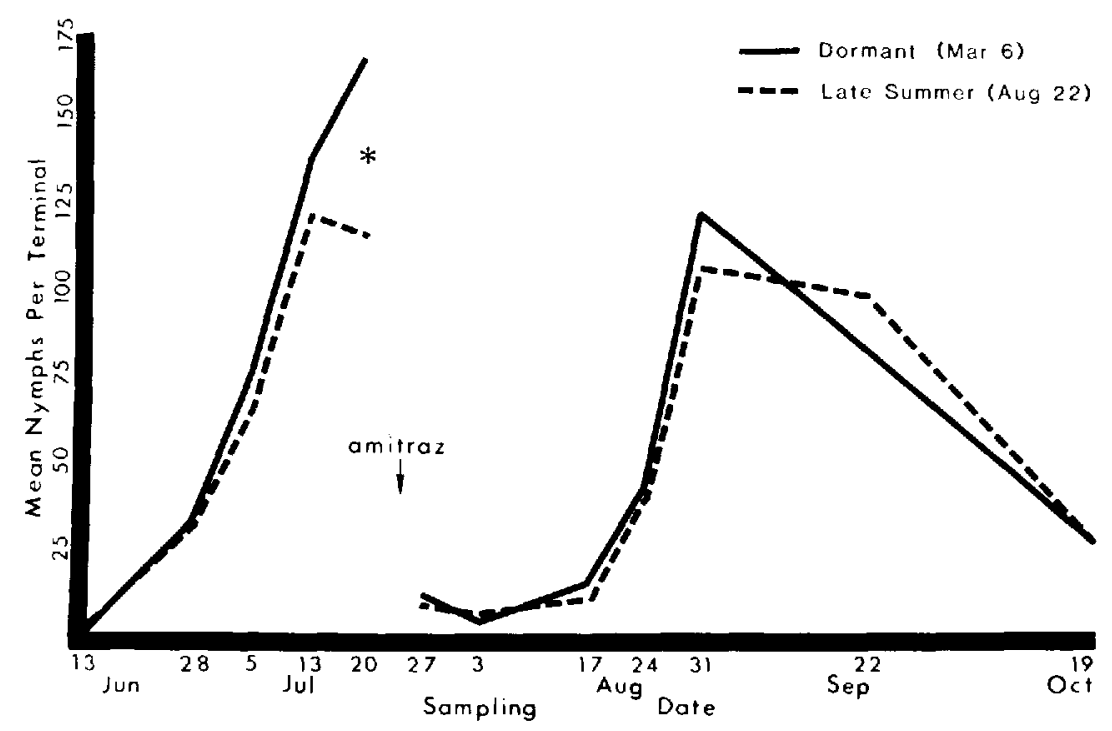

FIG. 3. Effect of fertilization date on pear psylla nymph numbers (Smith Tract, 1980). Asterisk indicates dates on which means are significantly different $(P<0.05)$.

Table 1. Significance levels for pear psylla numbers in a mature 'Anjou' pear orchard with differing rates and seasons of ammonium nitrate application (see Fig. 1 to 4) (Smith Tract, 1980)

\begin{tabular}{lccc}
\hline \multirow{2}{*}{ Source } & & Psylla stage \\
\cline { 2 - 4 } & Eggs & Nymphs & Adults \\
\hline & & & \\
Rate & $*$ & $*$ & NS \\
Season & NS & NS & NS \\
R $\times S$ & NS & NS & NS \\
Blocks & NS & NS & $*$ \\
Sampling date & $* *$ & $* *$ & $* *$ \\
$R \times D$ & $* *$ & NS & NS \\
S $\times D$ & NS & NS & NS \\
$R \times S \times D$ & NS & NS & NS \\
& & & \\
\hline
\end{tabular}

${ }^{a}$ ANOVA: ${ }^{* *}, P<0.01 ; *, P<0.05 ;$ NS,$P>0.05$

Table 2. Comparison of regression line slopes" for pear psylla populations in a mature 'Anjou' pear orchard with differing rates of ammonium nitrate application (Smith Tract, 13 June to 13 July $1980)^{k}$

\begin{tabular}{lccc}
\hline $\begin{array}{c}\text { Application } \\
\text { rate (kg of N) }\end{array}$ & Eggs & Nymphs & Adults \\
\hline 0.15 & $34.7 *$ & $23.8 *$ & 5.7 \\
0.45 & $70.3^{*}$ & 38.8 & 4.9 \\
\hline
\end{tabular}

aSlope for line describing number of psyllids per day.

${ }^{b}$ Paired $t$ test: ${ }^{*}, P<0.05$.

phal instars on high $\mathbf{N}$ trees on 24 April, 8 May, and 18 May; more 2nd instars on 18 May; more 3rd instars on 18 May and 1 June; 5th-instar numbers showed an application rate $\times$ season interaction on 9 June. An examination of this interaction showed that, at the higher $\mathrm{N}$ rate, dormant-fertilized trees had higher numbers of 5th instars than trees fertilized in late summer. This is probably because there was more $\mathrm{N}$ available in the spring when fruit trees exhibit their greatest growth and nitrogen requirement. There was no season effect at the lower $\mathrm{N}$ rate.

On dormant-fertilized trees higher $\mathrm{N}$ rate apparently resulted in greater numbers of 5 th instars $(P<0.01)$. On late-summer-fertilized trees, however, the lower $\mathrm{N}$ rate resulted in greater numbers $(P<0.05)$. With dormant-season fertilization the higher $\mathrm{N}$ rate apparently allowed greater translocation of $\mathrm{N}$ into the foliage resulting in more 5 th instars. This may have been a result of greater survival through the generation. The reverse effect in the late-summer-fertilized trees is harder to interpret. Perhaps some stress induced by the lower rate of $\mathrm{N}$ application, together with the time elapsed since the application was made, modified the nutritive quality of the tree by increasing phloem amino acid levels. The difference in numbers of 5 th instars favoring lower $\mathrm{N}$ trees in late-summer $\mathrm{N}$ applications was not as great as that favoring the higher rate of $\mathrm{N}$ application on dormant-fertilized trees. The greater complexity in 5th-instar-tree fertilization relations may be partly due to increasing effects over previous instars compounding to significance level by the 5 th instar.

Psyllid egg and nymph numbers in summer 1981 were substantially lower than in 1980 . The higher rate of fertilization led to increased adult numbers on 29 June. The adults gave rise to a greater number of eggs and Ist-instar nymphs on high-N trees compared with low$\mathrm{N}$ trees on 27 July and 13 July, respectively. Late-summer application led to greater egg numbers on 13 July, possibly an illustration of the importance of stored tree nitrogen. 
Table 3. Numbers of eggs laid per leaf by pear psylla in a choice trial using young and mature pear leaves

\begin{tabular}{|c|c|c|c|c|c|c|c|c|c|c|}
\hline Tissue age & & & & & Eggs/leaf & & & & & Mean \\
\hline Young & 81 & 64 & 62 & 55 & 46 & 46 & 44 & 26 & 18 & 49.1 \\
\hline Mature & 32 & 20 & 20 & 19 & 14 & 9 & 8 & 7 & 3 & 14.7 \\
\hline
\end{tabular}

aANOVA: $* * * P<0.01$.

Table 4. Fruit downgrading (downgrading index) due to pear psylla honeydew russet in a mature 'Anjou' pear orchard with differing rates and seasons of ammonium nitrate application (Smith Tract, 1980-1981) ${ }^{a}$

\begin{tabular}{|c|c|c|c|c|c|}
\hline \multirow{2}{*}{ Year } & \multirow{2}{*}{$\begin{array}{l}\text { Application } \\
\text { season }\end{array}$} & \multicolumn{3}{|c|}{ Application rate } & \multirow{2}{*}{ Mean } \\
\hline & & $0.15 \mathrm{~kg}$ of $\mathrm{N}$ & & $0.45 \mathrm{~kg}$ of $\mathrm{N}$ & \\
\hline \multirow[t]{3}{*}{1980} & Summer & 0.64 & & 0.80 & 0.72 \\
\hline & Dormant & 0.71 & & 0.84 & 0.78 \\
\hline & Mean & 0.68 & $* *$ & 0.82 & \\
\hline \multirow[t]{3}{*}{1981} & Summer & 0.36 & & 0.67 & $\begin{array}{r}0.52 \\
* *\end{array}$ \\
\hline & Dormant & 0.29 & & 0.50 & 0.40 \\
\hline & Mean & 0.32 & $* *$ & 0.58 & \\
\hline
\end{tabular}

${ }^{a}$ ANOVA: ${ }^{* *}, P<0.01$.

\section{Developmental Rate}

There was no difference between the WI curves for Smith Tract, but this result is ambiguous. It could be due to: a compensatory feeding response, as discussed by McNeill and Southwood (1978); an insufficient difference in foliar amino acids to make any difference in pear psylla development rate; or a continual input of new eggs on the orchard leaves.

In the growth room, the effect of $\mathrm{N}$ rate on WI curves was clearer (Fig. 4). A sigmoid nature is apparent. The WI curve for high-N trees was not different from that for low- $\mathrm{N}$ trees, but both were higher than the line for the medium- $\mathrm{N}$ trees; i.e., nymphs on medium- $\mathrm{N}$ trees developed at a slower rate than those on both low- and high-N trees. This was unexpected, since other homopterans reportedly develop faster with increasing foliar nitrogen (McClure 1980). Catling (1971) found that 2nd and 3rd instars of citrus psylla, Trioza erytreae (Del Guercio), developed faster on low-N Citrus seedlings, but he could not account for this. A second $T$. erytreae generation was tested, but the result was not repeated. The observed relationship could be accounted for by a compensatory feeding response to low $N$ (Pfeiffer 1982).

The effect of plant nitrogen on an herbivorous population may be complemented or reduced by other ecological factors. There may be a complementary effect between poor nutritional quality of the foliage and greater survival of natural enemies due to the lack of insecticidal sprays in such an orchard. McNeill and Southwood (1978) described how high plant nitrogen could raise the population growth rate above a "natural enemy ravine," decreasing relative natural control. It is also possible that high plant nitrogen could increase mortality due to natural enemies congregating in areas of high prey density.

Predator counts on most dates in 1981 were so low that statistical analysis was not warranted. On 27 July, however, large numbers of coccinellids were present. There were more lady beetles on the high-nitrogen trees ( 5.5 beetles per tray from high- $\mathrm{N}$ trees, 3.2 beetles per tray from low-N trees). This is most likely a response to greater pear psylla densities on those trees, albeit differences in numbers of nymphs were not as pronounced as in 1980. Predators were also more common in 1980 (up to seven anthocorids per tray [unpublished data]), although data were not collected that year.

\section{Damage}

There was greater fruit downgrading due to pear psylla honeydew russet on trees with higher fertilization in both 1980 and 1981 (Table 4). This is associated with higher psylla nymphal densities early in the season on trees receiving the higher $\mathrm{N}$ rate. These early-season differences in egg and nymph numbers are important, considering the lack of effective early-season biological control. There was no effect from season of nitrogen application on damage in 1980. In 1981, late-summerfertilized trees had more psylla-damaged fruit. This seasonal effect is difficult to interpret. In summer 1981 there were no seasonal differences in nymph numbers, although there were more pear psylla eggs on late-summer-fertilized trees on 13 July. Damage was less in 1981 than 1980. This may be a result of lower pear psylla densities in 1981. Apparently, the increase in predator numbers on higher- $\mathrm{N}$ trees did not affect pear psylla numbers enough to counteract the effect of increased foliar nitrogen.

There was no difference in fruit weight or in shoot length due to rate or season of nitrogen application. Fertilization rate and psylla populations would be expected to affect fruit weight and shoot growth in opposite directions. Thus, whereas higher $\mathrm{N}$ rates might stimulate shoot growth, they would also stimulate higher pear psylla populations which could then mask the $\mathrm{N}$ rate effect, inhibiting shoot growth.

Late-summer nitrogen application resulted in higher fruit bud density. Fruit buds are laid down in the year before their bloom and set. The late-summer $\mathrm{N}$ application may have added nutrients at an optimum time. Stored $\mathrm{N}$ could also be important in determining bud density. Although buds are differentiated shortly after the main period of shoot growth, post-differentiation 


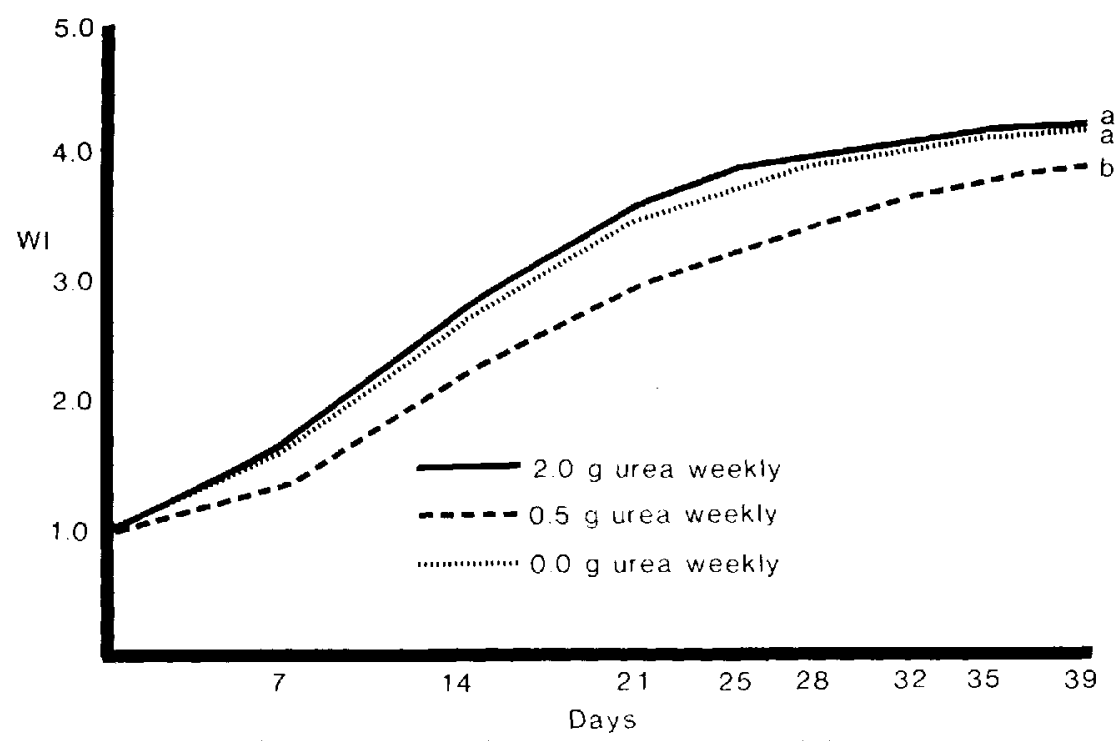

FiG. 4. WI curves for pear psylla nymphs on potted Bartlett seedlings with differing urea application rates. Lines followed by the same letter are not significantly different (LSMEANS: $P<0.05$ ).

factors could also be important. Westwood (1978) stated that bloom density was greater on fruit trees fertilized in late summer of the previous year. This was attributed to longer-lived embryo sacs. Fruit bud density was not affected by fertilization rate, but any potential effect may have been masked by pear psylla populations.

Analysis of fruit set showed a rate $\times$ season interaction. On late-summer-fertilized trees fruit set was higher on low-nitrogen trees, but on dormant-fertilized trees there was no rate effect. The lower fruit set at higher $N$ rate than lower $\mathrm{N}$ rate on late-summer-fertilized trees may have been due to high $N$ availability at a time critical to fruit set, keeping the tree in a vegetative state rather than a fruiting state. Perhaps the dormant application came too late to affect this. On low $-\mathrm{N}$ trees, fruit set was greater on late-summer-fertilized trees $(P<0.10)$. This may have been a result of the greater bud density on late summer-fertilized trees. On high- $\mathrm{N}$ trees there was no season effect.

Indirect damage to pear trees (effects on fruit size, shoot growth, bloom density and fruit set) by pear psylla could not be shown, due to the opposing effects of nitrogen supply and pear psylla densities on these parameters. Direct damage to fruit by psylla was shown to be affected by nitrogen treatment. Since differences in pear psylla nymphal populations were mostly limited to the early season, it is likely that early populations affected by nitrogen rates are responsible for the differences in honeydew russet, highlighting the need of earlyseason control of pear psylla and further studies on pear psylla-nitrogen interactions.

\section{REFERENCES CITED}

Burts, E. C. 1970. The pear psylla in central Washington. Wash. Agric. Exp. Stn. Circ. 516. 13 pp.
Burts, E. C., and A. H. Retan. 1969. Detection of pear psylla. Wash. State Univ. Ext. Mim. 3069. 2 pp.

Catling, H. D. 1971. The bionomics of the South African citrus psylla, Trioza erytreae (Del Guercio) (Homoptera, Psyllidae). 5. The influence of host plant quality. J. Entomol. Soc. S. Afr. 34: 381-391.

Chang, J. F., and B. J. R. Philogène. 1976. The development and behavior of the pear psylla, Psylla pyricola, (Homoptera: Psyllidae) on different pear rootstocks and cultivars. Phytoprotection 57: 137-149.

Croft, B. A., and S. C. Hoyt. 1978. Considerations for the use of pyrethroid insecticides for deciduous fruit pest control in the U.S.A. Environ. Entomol. 7: 627-630.

Forbes, A. R. 1972. Innervation of the stylets of the pear psylla, Psylla pyricola (Homoptera: Psyllidae), and the greenhouse whitefly, Trialeurodes vaporarium (Homoptera: Aleyrodidae). J. Entomol. Soc. B.C. 69: 27-30.

Helwig, J. T., and K. A. Council [eds.]. 1979. SAS user's guide, 1979 Ed. SAS Inst., Raleigh. 494 pp.

Hill, J. 1980. The remobilization of nutrients from leaves. J. Plant Nutr. 2: 407-444.

McClure, M. S. 1980. Foliar nitrogen: a basis for host suitability for elongate hemlock scale, Fiorinia externa (Homoptera: Diaspididae). Ecology 61: 72-79.

McNeill, S., and T. R. E. Southwood. 1978. The role of nitrogen in the development of insect/plant relationships. In J. B. Harboume [ed.], Biochemical aspects of plant and animal coevolution. Academic, Press, New York. 435 pp.

McVay, J. R., and H. C. Ellis. 1979. Extension approaches to pecan pest management in Alabama and Georgia, pp. 121-150. In D. J. Boethel and R. D. Eikenbary [eds.], Pest management programs for deciduous tree fruits and nuts. Plenum, New York. $256 \mathrm{pp}$

National Academy of Sciences. 1969. Insect-pest management and control. Vol. 3. Principles of plant and animal pest control. Publ. No. 1695, NAS, Washington, D.C. 508 pp.

Pfeiffer, D. G. 1982. The effect of tree nitrogen on pear psylla, Psylla pyricola Foerster. Ph.D. dissertation, Washington State University, Pullman. $80 \mathrm{pp}$. 
Watmough, R. H. 1968. Population studies on two species of Psyllidae (Homoptera, Sternorhynca) on broom (Sarothamnus scoparius (L.) Wimmer). J. Anim. Ecol. 37: 283-314.

Westwood, M. M. 1978. Temperate-zone pomology. Freeman, San Francisco, 428 pp.

White, T. C. R. 1970a. Some aspects of the life history, host selection, dispersal and oviposition of adult Cardiaspina densitexta (Homoptera: Psyllidae). Aust. J. Zool. 18: 105117.

1970b. The nymphal stage of Cardiaspina densitexta (Homoptera: Psyllidae) on leaves of Eucalyptus fasciculosa. Ibid. 18: $273-293$.

1978. The importance of a relative shortage of food in animal ecology. Oecologia 33: 71-86. 